\title{
Changing Behaviors of Adults for Ensuring the Food Hygiene During Covid-19 Outbreak: The Case of Turkey
}

\author{
Duygu Sağlam ${ }^{1}$ iD , Gözde Arıtıcı Çolak ${ }^{1}$ (iD , Murat Baş ${ }^{1}$ (iD
}

${ }^{1}$ Acibadem University, Health Sciences Faculty, Department of Nutrition and Dietetics, Istanbul, Turkey

Duygu SAĞLAM

Gözde ARITICI ÇOLAK

Murat BAŞ

Correspondence: Duygu Sağlam Acibadem Mehmet Aydinlar University, Faculty of Health Sciences, Department of Nutrition and Dietetics, Istanbul, Turkey

Phone: +902165004233

E-mail: duygu.saglam@acibadem.edu.tr

\section{ABSTRACT}

Objective: The aim of this study is to determine the behavior of individuals for buying, preparing, and cooking processes of the foods during the Covid-19 epidemic.

Materials and Methods: This study carried out with 999 adult individuals, $15.0 \%(n=150)$ men and $85.0 \%(n=849)$ women, aged 19-65. The questionnaire includes questions regarding the provision of food hygiene before and during the Covid-19 outbreak.

Results: While the preference rate for markets' take-out services increased in the Covid-19 epidemic process (22.8\% before Covid-19; 55.7\% in the Covid-19 outbreak), there was a decrease in the proportion of those who preferred neighborhood farm markets ( $66.8 \%$ before Covid-19; $27.5 \%$ during Covid-19 outbreak) $(p<0.01)$. The proportion of those who chose to buy packaged bread and fruit during the epidemic also increased $(p=0.001)$.

Conclusion: No scientific data are available on the consumption of nutrients with a potentially contaminated risk and the transmission of the virus. However, it is believed that the concerns about carrying this virus with food can be prevented by the consumers more carefully applying the routine hygiene rules.

Keywords: Behavior, COVID-19, food hygiene, SARS-CoV-2

Yetişkinlerin Covid-19 Salgını Sürecinde Besinlerin Hijyeninin Sağlanması Konusunda Değişen Davranışları: Türkiye Örneği

ÖZET

Amaç: Bu araştırmanın amacı bireylerin Covid-19 salgını sürecinde besinlerin satın alınması, hazırlanması ve pişirilmesi aşamalarındaki davranışlarını saptamaktır.

Gereç ve Yöntem: Bu çalışma, 19-65 yaş arası \%15,0'i $(n=150)$ erkek, \%85,0'i ( $n=849)$ kadın olmak üzere 999 yetişkin bireyler ile yürütülmüştür.

Bulgular: Ankette demografik veriler ile Covid-19 salgını öncesi ve sırası besin hijyeninin sağlanmasına yönelik davranışların sorgulandığı sorular bulunmaktadır. Covid-19 salgını sürecinde marketlerin eve servis hizmetlerinin tercih oranı artış gösterirken (Covid-19 öncesi \%22,8; Covid-19 sürecinde \%55,7); semt pazarlarını tercih edenlerin oranında azalma saptanmıştır (Covid-19 öncesi \%66,8; Covid-19 sürecinde \%27,5) ( $p<0,01)$. Salgın sürecinde ekmek ile meyve sebzeyi paketli almayı tercih edenlerin oranını da artı̧ göstermiştir (ekmek için salgın öncesi \%48,8; salgın sürecinde $\% 85,6$; sebze ve meyve için salgın öncesi $\% 24,3$, salgın sürecinde $\% 77,5)(p=0,001 ; p<0,01)$.

Sonuç: Olası bulaşan riski olan besinlerin tüketimi ile virüsün bulaştığına dair bugüne kadar bilimsel bir veri mevcut değildir. Ancak tüketicilerin rutin hijyen kurallarını her zamankinden daha dikkatle uygulamasıyla bu virüsün gıdalarla taşınması konusundaki endişelerin önüne geçilebileceği düşünülmektedir.

Anahtar Kelimeler: besin hijyeni, covid-19, davranış, SARS-CoV-2 
$\mathbf{T}$ he new type of coronavirus (Covid-19) is a highly contagious and pathogenic viral infection caused by severe acute respiratory syndrome coronavirus 2 (SARS-CoV-2), which is appeared in Wuhan, China and spread out to the world (1). It is stated that the main route of transmission is largely from person to person through inhalation (2). Covid-19, although there is no published evidence that contamination from an infected person's cough or sneeze, or contact with the food or food packaging he touches can cause the disease, the virus that causes Covid-19 can survive on the surfaces for a certain period of time (3). Determining all the points in contact with food and food packages and ensuring the hygiene of contaminated foods will be important in preventing the transmission of the virus, causing Covid-19 and reducing the concerns about foodborne contamination.

In this context, providing personal hygiene during the food contact process and good hygiene practices for food safety in the kitchen will reduce the risk for all contaminants (4). The aim of this study is to determine the behavior of adult individuals about the factors that may pose a risk for possible Covid-19 contaminants from food or food packaging.

\section{Material and Methods}

\section{Study Population and Design}

This study was conducted with adult individuals aged 19-65 who agreed to participate in the study between 20 March and 20 April 2020. The data collection tool is a questions developed by the researchers. Before develop the questions, self-reported consumer purchasing and food handling behaviors during the beginning phase of the COVID-19 pandemic were asked to students who educated at Acibadem University Nutrition and Dietetic Department. A final questions were created by evaluating these data that students noted. The final questions were transferred to the electronic environment via the "Google Survey" and the survey data were collected by the haphazard sampling method. 1086 individuals filled out the questions created in the electronic environment; 87 of these individuals were excluded from the study because they answered the questions incompletely. Thus, the study was completed with 999 people.

\section{Instrumentations}

At the beginning of the questions, there is a text stating that the information of the person carrying out the research is based on volunteering, and the information of the individual who filled the questionnaire will be kept in secret. The fact that individuals read and approve the form means that they agree to participate in the study.

The developed questions consists of two sections. These sections are demographic Information (including their age, gender, and educational background) and questions for the asssessment of behaviors for providing food hygiene before and during the covid-19 outbreak (such as individuals ordering food from outside, preferring street markets, whether they prefer bread with packages or not)

\section{Results}

Table 1 summarizes the demographic characteristics of the individuals participating in the research. The study was carried out with a total of 999 cases, $15.0 \%(n=150)$ male and $85.0 \%(n=849)$ female. The ages of the cases ranged between 16 and 65 , with an average of $32.04 \pm$ 11.99 years (Table 1 ).

\begin{tabular}{|c|c|c|c|}
\hline & & $\begin{array}{l}\text { Min-Max } \\
\text { (Median) }\end{array}$ & Mean \pm Sd \\
\hline \multicolumn{2}{|l|}{ Age (Years) } & $16-65(27)$ & $32.04 \pm 11.99$ \\
\hline & & $\mathrm{n}$ & $\%$ \\
\hline \multirow{2}{*}{ Gender } & Male & 150 & 15.0 \\
\hline & Female & 849 & 85.0 \\
\hline \multirow{2}{*}{ Maritial Status } & Married & 448 & 44.8 \\
\hline & Single & 551 & 55.2 \\
\hline \multirow{4}{*}{ Education Level } & $\begin{array}{l}\text { Elementory School } \\
\text { and Below }\end{array}$ & 44 & 4.4 \\
\hline & High School & 255 & 25.5 \\
\hline & University & 600 & 60.1 \\
\hline & Master's Degree & 100 & 10.0 \\
\hline \multirow{4}{*}{ Occupation } & $\begin{array}{l}\text { Not Working/House } \\
\text { Wife }\end{array}$ & 226 & 22.7 \\
\hline & $\begin{array}{l}\text { Working (Worker/ } \\
\text { Self-Employement/ } \\
\text { Civil Servant) }\end{array}$ & 400 & 40 \\
\hline & Student & 293 & 29.3 \\
\hline & Retired & 80 & 8.0 \\
\hline
\end{tabular}

Table 2 shows the behaviors of eating habits acquired during the Covid-19 outbreak process. When it is asked about the meal preferences of individuals who continue to work during the Covid-19 outbreak ( $n=219$ ); $30.6 \%$ ( $n$ $=67$ ) of the cases stated that they ate at the cafeteria at work and $57.5 \%(n=126)$ were taking meals from home (Table 2). 


\begin{tabular}{|l|l|l|l|}
\hline \multicolumn{2}{|l|}{} & $\mathrm{n}$ \\
\hline \multirow{4}{*}{$\begin{array}{l}\text { The preference of eaten outside of the individuals who continue to work during this period } \\
(\mathrm{n}=219)\end{array}$} & Eating in the launch hall at work & 67 & 30.6 \\
\cline { 2 - 4 } & Taking food from home & 126 & 57.5 \\
\cline { 2 - 4 } & Ordering take out & 18 & 8.2 \\
\cline { 2 - 4 } Status of Changing habits of food purchase, storage, and cooking in the epidemic process & Buying from a bakery etc. & 8 & 3.7 \\
\cline { 2 - 4 } & Yes & 868 & 86.9 \\
\hline \multirow{2}{*}{ Status of thinking about continuing acquired habits after the outbreak } & Yes & 13.1 \\
\cline { 2 - 4 } & No & 859 \\
\hline
\end{tabular}

Table 3: Evaluation of Behaviors of Food Purchase Before and During Covid-19 Outbreak

\begin{tabular}{|c|c|c|c|c|c|}
\hline & \multicolumn{2}{|c|}{ Before the Covid-19 Outbreak } & \multicolumn{2}{|c|}{ During the Covid-19 Outbreak } & \multirow{2}{*}{${ }^{\mathrm{a}} p$} \\
\hline & $\mathrm{n}$ & $\%$ & $\mathrm{n}$ & $\%$ & \\
\hline I prefer to order ready meals from outside. & 325 & 32.5 & 18 & 1.8 & $0.001^{* *}$ \\
\hline $\begin{array}{l}\text { If I have to order ready meals from the outside, I prefer the food I } \\
\text { order to be cooked meals. }\end{array}$ & 876 & 87.7 & 912 & 91.3 & $0.009^{* *}$ \\
\hline I prefer street markets. & 667 & 66.8 & 275 & 27.5 & $0.001^{* *}$ \\
\hline I prefer the take-out services of the markets first. & 228 & 22.8 & 556 & 55.7 & $0.001^{* *}$ \\
\hline I wear gloves when I am shopping in the market. & 43 & 4.3 & 773 & 77.4 & $0.001 * *$ \\
\hline I pay attention to that the fruits and vegetables are packed. & 243 & 24.3 & 774 & 77.5 & $0.001^{* *}$ \\
\hline I pay attention to prefer fruits that can be peeled. & 488 & 48.8 & 818 & 81.9 & $0.001^{* *}$ \\
\hline I would not prefer to buy raw (such as rocket, lettuce) vegetables. & 55 & 5.5 & 155 & 15.5 & $0.001^{* *}$ \\
\hline I prefer frozen vegetables first. & 69 & 6.9 & 224 & 22.4 & $0.001^{* *}$ \\
\hline I prefer to get my bread packed. & 493 & 49.3 & 855 & 85.6 & $0.001^{* *}$ \\
\hline I prefer to buy packaged foods such as meat, chicken, and fish. & 670 & 67.1 & 829 & 83.0 & $0.001^{* *}$ \\
\hline a Pearson Chi-Square Test & & ${ }^{*} p<0.01$ & & & \\
\hline
\end{tabular}

Table 3 shows the behavior of food buying before and during the Covid-19 outbreak. While $32.5 \%$ of the cases prefer to order ready meals from outside before the outbreak, this rate fell to $1.8 \%$ during the outbreak $(p=0.001$; $p<0.01$ ). While those who prefer street markets before the outbreak are $66.8 \%$; This rate has decreased to $27.5 \%$ during the epidemic outbreak ( $p=0.001 ; p<0.01$ ). While $24.3 \%$ ( $n=243$ ) of the cases were careful to be packed fruits and vegetables before the outbreak; this rate increased to $77.5 \%(n=774)$ during the outbreak $(p=0.001 ; p$ $<0.01)$.

Table 4 describes the behaviors regarding food preparation and cooking before and during the Covid-19 outbreak. While $66.5 \%$ of the cases came home from the market, washing my hands with soapy water for at least 20 seconds before the outbreak; this rate increased to $99.3 \%$ during the outbreak $(p=0.001 ; p<0.01)$.
Table 5 shows the behavioral changes shown during the outbreak according to the descriptive features. There was a statistically significant difference between the behavior change rates by gender ( $p=0.040 ; p<0.05)$, and the rate of change in women was higher than that of men. Behavior change rates according to marital status, do not differ statistically $(p>0.05)$.

\section{Discussion}

Although there is no up-to-date data on contamination of Covid-19 with food consumption (5), it has been determined that there are changes in individuals' food buying habits in the Covid-19 outbreak. An increase in the food and beverage sector in Turkey is observed due to reasons such as urbanization, rising income levels, an increase in the number of working women, and the young population (6). In this study $22.8 \%$ of individuals prefer the home service of the markets before the Covid-19 outbreak, this rate increased to $55.7 \%$ in the outbreak $(p<0.01)$ (Table 3$)$. 
Table 4: Assessment of Behaviors Regarding Food Preparation and Cooking Before and During the Covid-19 Outbreak

\begin{tabular}{|c|c|c|c|c|c|}
\hline & \multicolumn{2}{|c|}{ Before the Covid-19 Outbreak } & \multicolumn{2}{|c|}{ During the Covid-19 Outbreak } & \multirow{2}{*}{${ }^{\mathrm{a}} p$} \\
\hline & $\mathrm{n}$ & $\%$ & $\mathrm{n}$ & $\%$ & \\
\hline $\begin{array}{l}\text { When I come home from the market, I wash my hands with soap } \\
\text { for at least } 20 \text { seconds. }\end{array}$ & 664 & 66.5 & 992 & 99.3 & $0.001^{* *}$ \\
\hline $\begin{array}{l}\text { I keep the grocery bags that I put the food which I bought from } \\
\text { the market. }\end{array}$ & 758 & 75.9 & 294 & 29.4 & $0.001^{* *}$ \\
\hline $\begin{array}{l}\text { I put the food that I brought home from the supermarket on the } \\
\text { balcony / in front of the door for a while and then take it home. }\end{array}$ & 155 & 15.5 & 772 & 77.3 & $0.001^{* *}$ \\
\hline $\begin{array}{l}\text { I wipe the package of packaged food/drinks I bought with soap } \\
\text { or diluted bleach. }\end{array}$ & 153 & 15.3 & 731 & 73.2 & $0.001^{* *}$ \\
\hline $\begin{array}{l}\text { I clean the bottles of the carboy or other plastic bottles of the } \\
\text { water I ordered with soap or bleach diluted with water. }\end{array}$ & 251 & 25.1 & 772 & 77.3 & $0.001^{* *}$ \\
\hline $\begin{array}{l}\text { I take the vegetables/fruits out of their bags and put them in the } \\
\text { fridge. }\end{array}$ & 713 & 71.4 & 760 & 76.1 & $0.017^{*}$ \\
\hline I leave the vegetables to be consumed raw in water with vinegar. & 758 & 75.9 & 885 & 188.6 & $0.001^{* *}$ \\
\hline I wash the vegetables to be consumed raw with soapy water. & 62 & 6.2 & 186 & 18.6 & $0.001^{* *}$ \\
\hline I put the eggs in the fridge, after washing them. & 159 & 15.9 & 324 & 32.4 & $0.001^{* *}$ \\
\hline $\begin{array}{l}\text { I cook more to make sure that food like meat, chicken, fish is } \\
\text { cooked well. }\end{array}$ & 805 & 80.6 & 882 & 88.3 & $0.001^{* *}$ \\
\hline aPearson Chi-Square Test & & $p<0.01$ & & & \\
\hline
\end{tabular}

\begin{tabular}{|c|c|c|c|c|c|}
\hline & & \multirow[b]{2}{*}{$n$} & \multicolumn{2}{|c|}{$\begin{array}{c}\text { Behavior change rate is shown during } \\
\text { Covid-19 outbreak (\%) }\end{array}$} & \multirow{2}{*}{$p$} \\
\hline & & & Min-Max. (Median) & Mean \pm Sd & \\
\hline \multirow{2}{*}{ Age (year) } & $r$ & 999 & \multicolumn{2}{|c|}{-0.058} & \\
\hline & $p$ & & \multicolumn{2}{|c|}{0.069} & \\
\hline \multirow{2}{*}{ Gender } & Male & 150 & $0-85.7(33.3)$ & $30.98 \pm 21.64$ & ${ }^{b} 0.040^{*}$ \\
\hline & Female & 849 & $0-90.5(33.3)$ & $34.86 \pm 17.99$ & \\
\hline \multirow{2}{*}{ Marital Status } & Married & 448 & $0-76.2(33.3)$ & $33.17 \pm 18.26$ & ${ }^{b} 0.090$ \\
\hline & Single & 551 & $0-90.5(38.1)$ & $35.18 \pm 18.87$ & \\
\hline \multirow{4}{*}{ Education Status } & Elementory School and below & 44 & $0-71.4(31)$ & $29.55 \pm 20.06$ & ${ }^{\circ} 0.059$ \\
\hline & High School & 255 & $0-90.5(33.3)$ & $32.53 \pm 19.01$ & \\
\hline & University & 600 & $0-85.7(38.1)$ & $34.87 \pm 18.36$ & \\
\hline & Master's Degree & 100 & $0-81(38.1)$ & $37.33 \pm 18.02$ & \\
\hline \multicolumn{2}{|l|}{ r:Pearson Correlation C } & \multicolumn{2}{|c|}{ 'Oneway ANOVA Test } & ${ }^{*} p<0.05$ & \\
\hline
\end{tabular}

Food shopping from the internet is not common in Turkey (7). In this study, it is estimated that the reason for increasing markets' take-out services and decreasing online food order in the outbreak may be the desire to reduce the contact of people with the food in the process of food purchase. Neighbour markets are shopping organizations that are established on certain days and places, which allow families to buy their needs (8). While those who prefer street markets are $66.8 \%$ before the outbreak, dropped to $27.5 \%$ during the outbreak $(p<0.01)$.
Stages such as food packaging, transportation, and storage significantly increase the risk of contamination, and the human factor is also considered as environmental contaminants (9). Therefore, the possible SARS-CoV-2 infected individual involved in the food supply chain may be a risk factor for the transmission of the virus to the surfaces. In this direction, $77.5 \%$ of the individuals participating in the research pay attention to the fact that fruits and vegetables should be packed during the Covid-19 outbreak. This rate was found to be $24.3 \%$ before the outbreak. It was 
observed that the fruit and vegetable have started to be sold in bags in many supermarkets and neighboring markets in Turkey. Similarly, during the outbreak, bread was preferred to be packaged more $(p<0.01)$ (Table 3$)$.

According to the guidelines published by the World Health Organization on the rational use of personal protective equipment during the Covid-19 outbreak, individuals who do not have respiratory symptoms in public areas do not need to use personal protective equipment (10). It is recommended to wipe the frequently contacted surfaces such as grocery baskets and cards with disinfectant wipes if possible, and use hand disinfectant after payment at the cash desk (5). $77.4 \%$ of the individuals participating in the research use gloves while shopping in the Covid-19 outbreak period (Table 3). If the individual prefers to use gloves, the glove removal steps (11) developed to prevent the possible pathogens on the surface of the gloves from being contaminated by the individual should be carefully followed.

Studies indicate that hand washing by preventing contamination by providing suitable conditions can reduce the risk of upper respiratory tract infection by $6 \%$ and $44 \%$ $(12,13)$. It is. found that hand rubbing with water and soap or alcohol-based products reduced Influenza A virus on the hand (14). In this study $99.3 \%$ of the participants wash their hands with soap for at least 20 seconds when they came home from the market during the outbreak, and this increase was found statistically significant $(p<0.01)$ (Table 4).

Surface cleaning is an important factor in ensuring hygiene in the kitchen. While surface cleaning with water and soap ensures the reduction of microbial load, disinfectants cause the death of pathogens on the surface (15). For disinfection, bleach solution containing sodium hypochlorite in $0.1 \%$ dilution can be used, or if bleach solution containing $5.25-6.00 \%$ sodium hypochlorite will be used, it can be diluted with 1/50 of water. Alcohol can also be used for surfaces where bleach is not suitable. (16). Apart from that, there are also disinfectants accepted by the Environmental Protection Agency for use against the virus that causes Covid-19 in America (17). In this study, we questioned the wiping of the package of packaged food/beverage purchased before and during the Covid-19 outbreak with soapy water or diluted bleach available at home. $15.3 \%$ of the individuals before the outbreak and $73.2 \%$ after the outbreak answered this question as "yes" (Table 4). Washing vegetables and fruits with water before consumption is necessary to remove pathogens. The surface can be washed by using a small amount of soap and water and a vegetable brush because the coronavirus is an enveloped virus and surrounded by an oily membrane (18). While those who kept the vegetables that can be consumed raw kept in water with vinegar were $88.6 \%$ during the outbreak $(p<0.01)$. Organic acids are defined as powerful antimicrobial agents due to reasons such as lowering the $\mathrm{pH}$ of the environment, impairing membrane permeability, and anion accumulation (19). In addition to acetic acid in the vinegar, $\mathrm{pH}$ value and phenolic compounds may cause an antibacterial effect (20). In a study the effects of home-made compounds on pathogens were investigated. According to the results of the research, when the effects of all tested pathogens from highest to lowest are evaluated; The most effective compounds are determined as $0.0314 \%$ sodium hypochlorite, $3 \%$ hydrogen peroxide, undiluted vinegar, and $5 \%$ acetic acid, $5 \%$ citric acid and baking powder (50\% sodium bicarbonate) respectively (21). However, many studies in the literature are on the antibacterial effect of vinegar (20-22).

Microbial safety of the egg is required. Since the natural protective layer on the shell will disappear with washing, the microorganism load may increase as the entrance of the microorganisms to the egg can be easier to (23). In this study, $15.9 \%$ of individuals before the Covid-19 outbreak; $32.4 \%$ of them put the eggs they bought in the refrigerator after washing during the epidemic of Covid-19, and this increase is statistically significant $(p<0.01)$. Another factor in ensuring food hygiene is the cooking temperature of foods such as meat, chicken, and fish. Coronaviruses are not heat-resistant, meaning that they are sensitive to normal cooking temperatures $\left(70^{\circ} \mathrm{C}\right)(24)$. In this study, the rate of those who cooked foods more increased compared to the pre-epidemic period $(p<0.01)$ (Table 4).

The fact that the data could not be taken face-to-face and that people of different socio-cultural levels could not be reached due to the online survey is the limitation of the research. Since the use of masks in public transportation and in public places is mandatory in our country, the use of masks has not been questioned in the scope of the research. On the other hand, basic rules such as the use of masks, attention to social distance protection, and physical contact in the markets could be questioned. 


\section{Conclusion}

Our research is the first study showing the changing behavior regarding hygiene in food during the Covid-19 outbreak in Turkey. The individuals participating in the research state that their habits have changed during the epidemic and that these habits will continue in the future. However, we think that the behavior of individuals may differ at different stages of the outbreak. For this reason, we foresee that there may be a difference in the attitudes and behaviors of individuals in future studies to be conducted for this purpose.

\section{Declarations}

Funding: The author(s) received no financial support for the research, authorship, and/or publication of this article.

Conflicts of interest: None of the authors has any conflict of interest to declare.

Ethics approval: The protocol of the study was approved by the Ethical Committee of the Acibadem Mehmet Aydinlar University with the number of 202-05/31.

Authors' contributions: Duygu Sağlam, Gözde Arıtıcı Çolak and Murat Baş contributed to the design and implementation of the research, to the analysis of the results and to the writing of the manuscript.

\section{References}

1. Centers for Disease Control and Prevention. (2020a). 2019 Novel Coronavirus, (2020). Retrieved from https://www.cdc.gov/ coronavirus/2019-ncov/about/transmission.html

2. Guo YR, QD Cao, ZS Hong, et al. The origin, transmission and clinical therapies on coronavirus disease 2019 (COVID-19) outbreak-an update on the status. Military Medical Research, 2020, 7.1: 1-10.

3. Van Doremalen N, Bushmaker T and Morris DH. Aerosol and surface stability of SARS-CoV-2 as compared with SARS-CoV-1. New England Journal of Medicine, 2020, 382.16: 1564-1567.

4. U.S. Food and Drug Administration. (2020). Coronavirus Disease 2019 (COVID-19) and the Food Supply Chain. https:// www.fda.gov/food/food-safety-during-emergencies/ food-safety-and-coronavirus-disease-2019-covid-19

5. Desai, AN and Aronoff, DM. Food Safety and COVID-19. Jama, 2020, 323.19: 1982-1982.

6. Oktay K and Kızı GK. Türk Dünyası ülkelerinde online yemek satış siteleri üzerine bir araştırma. Manas Sosyal Araştırmalar Dergisi, 2017, 6.5: 147-162.

7. Büyükköroğlu AM. E-Ticaret Yoluyla Gıda Maddeleri Satın Almaya Yönelik Tokat II Merkezinde Yaşayan Tüketicilerin Tutumunu Etkileyen Faktörlerin Analizi. Gaziosmanpaşa Üniversitesi Fen Bilimleri Enstitüsü Tarım Ekonomisi Ana Bilim Dalı Yüksek Lisans Tezi, Tokat, 2011, 18.

8. Tunçel $\mathrm{H}$. Anadolu şehirlerinde semt pazarları: Elazığ örneği. Fırat Üniversitesi Sosyal Bilimler Dergisi, 2003, 13.1: 49-70.
9. Gizaw, Zemichael. Public health risks related to food safety issues in the food market: A systematic literature review. Environmental health and preventive medicine, 2019, 24.1: 68.

10. World Health Organization. (2020b). Rational use of personal protective equipment for coronavirus disease (COVID-19): interim guidance, 27 February 2020 (No. WHO/2019-nCov/IPCPPE use/2020.1). World Health Organization.

11. Centers for Disease Control and Prevention. (2020b). How to Remove Gloves. Retrieved from https://www.cdc.gov/vhf/ebola/pdf/posterhow-to-remove-gloves.pdf

12. Fung $\mathrm{ICH}$ and Carncross S. Effectiveness of handwashing in preventing SARS: a review. Tropical medicine \& international health, 2006, 11.11: 1749-1758.

13. Larson E. A causal link between handwashing and risk of infection? Examination of the evidence. Infection Control \& Hospital Epidemiology, 1988, 9.1: 28-36.

14. Grayson ML, Melvani, S, Druce, J et al. Efficacy of soap and water and alcohol-based hand-rub preparations against live H1N1 influenza virus on the hands of human volunteers. Clinical Infectious Diseases, 2009, 48.3: 285-291.

15. Centers for Disease Control and Prevention. (2020c). Cleaning and Disinfection for Households. Retrieved from https://www.cdc.gov/ coronavirus/2019-ncov/prevent-getting-sick/cleaning-disinfection. html

16. National Environment Agency. Interim Guidelines for Environmental Cleaning and Disinfection of Areas Exposed to Confirmed Case(s) of 2019 Novel Coronavirus (2019-nCoV) in Non-Healthcare Commercial Premises. Available at https://www.nea.gov.sg/ . Accessed May 5, 2020

17. U.S. Environmental Protection Agency. (2020). List N: Disinfectants for Use Against SARS-CoV-2. Retrieved from https://www.epa.gov/ pesticide-registration/list-n-disinfectants-use-againstsars-cov-2

18. Sağdıç O, Kayacan S, Dertli E et al. Gıda Güvenliği Açısından COVID-19 Etmeni SARS-CoV-2'nin Değerlendirilmesi ve Korunma Yöntemleri. Avrupa Bilim ve Teknoloji Dergisi, 2020, 18: 927-933.

19. Ramos B, Miller FA, Brandão TRS et al. Fresh fruits and vegetablesan overview on applied methodologies to improve its quality and safety. Innovative Food Science \& Emerging Technologies, 2013, 20: 1-15.

20. Kelebek H, Kadiroğlu P, Demircan NB et al. Screening of bioactive components in grape and apple vinegars: Antioxidant and antimicrobial potential. Journal of the Institute of Brewing, 2017, 123.3: 407-416.

21. Yang $H$, Kendall PA, Medeiros $L$ et al. Inactivation of Listeria monocytogenes, Escherichia coli O157: H7, and Salmonella typhimurium with compounds available in households. Journal of food protection, 2009, 72.6: 1201-1208.

22. Bakır $S$, Devecioğlu D, Kayacan $S$ et al. Investigating the antioxidant and antimicrobial activities of different vinegars. European Food Research and Technology, 2017, 243.12: 2083-2094.

23. Unusan, N. Yumurtanın evlerde hijyenik olarak kullanılmasının belirlenmesi arastırması. Saglık ve Toplum, 2001, 11.3: 57-60.

24. WHO (World Health Organization). (2020d). Coronavirus disease 2019 (COVID-19) Situation Report - 32. https://www.who.int/docs/ default-source/coronaviruse/situation-reports/20200221-sitrep-32covid-19.pdf?sfvrsn=4802d089_2 